\title{
ASSET ALLOCATION AND INFORMATION OVERLOAD: THE INFLUENCE OF INFORMATION DISPLAY, ASSET CHOICE AND INVESTOR EXPERIENCE
}

\author{
Julie Agnew* \\ Lisa R. Szykman \\ CRR WP 2004-15 \\ Released: May 2004 \\ Draft Submitted: April 2004 \\ Center for Retirement Research at Boston College \\ 550 Fulton Hall \\ 140 Commonwealth Ave. \\ Chestnut Hill, MA 02467 \\ Tel: 617-552-1762 Fax: 617-552-1750 \\ http://www.bc.edu/crr
}

* Julie Agnew is an assistant professor of finance and economics in the William and Mary School of Business Administration. Lisa R. Szykman is an assistant professor in the William and Mary School of Business Administration. The research reported herein was performed pursuant to a grant from the U.S. Social Security Administration (SSA) to the Center for Retirement Research at Boston College (CRR). The opinions and conclusions are solely those of the authors and should not be construed as representing the opinions or policy of the SSA or any agency of the Federal Government or of the CRR. The authors thank Megan Clark for her invaluable research assistance.

(C) 2004, by Julie Agnew and Lisa R. Szykman. All rights reserved. Short sections of text, not to exceed two paragraphs, may be quoted without explicit permission provided that full credit, including (C) notice, is given to the source. 


\section{About the Center for Retirement Research}

The Center for Retirement Research at Boston College, part of a consortium that includes parallel centers at the University of Michigan and the National Bureau of Economic Research, was established in 1998 through a grant from the Social Security Administration. The goals of the Center are to promote research on retirement issues, to transmit new findings to the policy community and the public, to help train new scholars, and to broaden access to valuable data sources. Through these initiatives, the Center hopes to forge a strong link between the academic and policy communities around an issue of critical importance to the nation's future.

\section{Center for Retirement Research at Boston College}

550 Fulton Hall

140 Commonwealth Ave.

Chestnut Hill, MA 02467

phone: 617-552-1762 fax: 617-552-1750

e-mail: crr@bc.edu

http://www.bc.edu/crr

Affiliated Institutions:

American Enterprise Institute

The Brookings Institution

Massachusetts Institute of Technology

Syracuse University

Urban Institute 


\begin{abstract}
This paper investigates three common differences among DC plans that may lead to varying degrees of information overload. We hypothesize that information overload is one reason DC participants often choose the default options. In two experiments, we manipulate the display of the investment information, the number of choices offered, and the similarity of these choices. In addition, we measure the financial knowledge of the participants. We test how these factors influence the participant's feelings of information overload, decision satisfaction and choice of the default. The main contribution of this analysis is that it explores the interaction between the individual's tested financial knowledge and the manipulated plan features. In our study, women with relatively lower salaries and less education tend to fall into our low knowledge category. Our findings do show that changes to plan design can help some individuals. We find individuals with above average financial knowledge do report significantly less overload when given fewer investment choices. This confirms previous research that plan design is important. Our results also show that financial knowledge plays a large role in who opts for the default. We find that low knowledge individuals opt for the default allocation more often than high knowledge individuals (experiment one: $20 \%$ vs. $2 \%$ ). Our findings suggest individuals with below average knowledge are simply overwhelmed by the investment decision in general. Altering the plan by offering investment information in a more easily comparable format or by reducing the choices offered does not attenuate the low knowledge individuals' feelings of overload. The findings suggest that the success of certain plan features depends strongly on the financial background of the participant. The results emphasize the importance of plan design, especially the careful selection of plan default options, and the need to improve the financial literacy of participants.
\end{abstract}

Key words: 401(k), investments, information overload, financial knowledge 


\section{Asset Allocation and Information Overload: The Influence of Information Display, Asset Choice and Investor Experience}

\section{Introduction}

For many individuals, their financial security during retirement depends on the financial decisions they make in their defined contribution plans today. Yet despite the importance of these investment decisions, growing research shows that individuals are not making choices that best fit their needs (see, e.g., Agnew, 2003; Benartzi, 2001, Munnell and Sundén, 2004). In fact, strong evidence suggests defined contribution plan participants tend to make choices based on the "path of least resistance" (Choi, Laibson, Madrian and Metrick, 2002). One consequence of this behavior is that many individuals invest according to their plans' default options. Accepting the default options defeats the purpose of a self-directed investment account and, depending on the default options, can have an adverse affect on the participant's savings. Understanding what is driving this behavior and how plan administrators can help to alleviate the problem is an issue of critical importance. The significance of this issue is highlighted by the fact that over fifty million individuals participated in defined contribution plans in 1998 and by the fact that a debate on whether voluntary private accounts should be introduced into the Social Security system is currently being waged in Washington (EBRI, 2003).

Literature suggests that procrastination, the status quo bias, and anticipated regret are all reasons for individuals' tendency to follow the path of least resistance (Choi, Laibson, Madrian and Metrick, 2003; Madrian and Shea, 2001). In this paper, we offer an 
additional explanation for individuals' reluctance to make investment decisions in their defined contribution plans. We hypothesize that these participants are experiencing information overload. In other words, these participants are becoming overwhelmed when making their decision and as a result they look for an easy way out, the default. Research in the decision-making literature suggests that rather than processing more information when decisions become more complex, consumers tend to reduce the amount of effort they expend in order to make their decision or choice (Payne, Bettman and Johnson, 1988; Payne, Bettman and Luce, 1996). Therefore, it seems intuitive that if plan administrators can structure the choice environment to simplify the decision, they can attenuate investors' feelings of overload. The benefit of this action is that participants will be more likely to effectively evaluate their choice alternatives and make informed decisions.

Motivated by previous research showing the strong influence of plan design on investment behavior, this paper investigates three common differences among plans that may lead to varying degrees of overload. In particular, in two experiments we manipulate the display of the investment information, the number of choices offered, and the similarity between the investment options that are offered. The goal is to investigate if participants are experiencing varying degrees of overload as a result of these changes. In addition, we measure the financial knowledge of all the participants and include this measure as an independent variable in the study. The main contribution of this analysis is that it explores the interaction between the individual's tested financial knowledge and the manipulated plan features. The results emphasize the importance of plan design, 
especially the careful selection of plan default options, and the need to improve the financial literacy of participants.

The remainder of this paper is organized as follows. In Section 2 we present a review of the existing literature. Section 3 includes a description of participants in the experiments and a discussion of their performance on the financial literacy exam. In Section 4 and Section 5, we describe the methodology and the results from experiment one and experiment two, respectively. Section 6 concludes our paper with a summary discussion of our findings and their implications.

\section{Background}

A growing body of literature in finance and economics suggests that the design of defined contribution plans can influence investment behavior (see, e.g., Choi et al., 2002). Notably, seemingly benign decisions made by employers can have a large influence on participation rates, contribution levels and asset allocation choices. For example, the presence of an employer match can positively influence participation and contribution levels in plans (for a summary of the literature, see Munnell, Sundén and Taylor, 2001/2002). In addition, individuals tend to invest more of their discretionary allocations to company stock when the employer match is in company stock (Benartzi, 2001). Recognizing the influence of plan design, some employers have introduced plan features that encourage participants to make better decisions. For example, participation levels and contribution levels have been increased by introducing such plan features as automatic enrollment plans and savings plans (see, e.g., Choi, Laibson, Madrian and Metrick, forthcoming; Thaler and Benartzi, 2004). 
This paper investigates how plan design can influence one current problem in defined contribution plans - the prevalence of individuals investing according to their plans' default options. The tendency for individuals to choose their default options is highlighted in a study by Choi et al., (forthcoming). They found that 80 percent of participants in plans with automatic enrollment initially accepted the plan's low default savings rate and the conservative default investment fund. Three years later, over half of these individuals maintained these same default elections.

So what is wrong with the default election? For one, default options are not generally optimized for the individual. Typically, plans offer "one-size-fits-all” defaults that tend to be conservative. As a result, investment in the default options often results in inadequate savings for many individuals. Second, it suggests that individuals are not carefully considering their options, which may have an adverse effect on one's future financial security.

As was mentioned earlier, one reason for this phenomenon could be that individuals are experiencing information overload while making their investment decisions. A number of variables may be contributing to their overload. One source could be how information about choices is presented to the investors. Effectively communicating choice information has long been a topic of interest for public policy makers and consumer researchers. Simply providing more information about investment options may not be enough to help investors make good decisions. As predicted in the economics of information literature, consumers will tend to use information more extensively if it costs less time and/or money to acquire (Stigler, 1961; Nelson ,1970, 1974). This suggests that when information is easier to obtain and evaluate, consumers 
are more likely to use it when making decisions or choices. For example, the nutritional labeling literature shows that standardized information presented in labels and claims made a difference in how consumers used the information and made their product choice. As dependable information becomes easier to use, consumers employ the information more to determine food quality, acquire more nutrition information prior to purchase, and improve their overall decision quality (Roe, Levy and Derby, 1999; Ippolito and Mathios 1990, 1994; Moorman 1990, 1996; Muller 1985). Therefore, if information about investment options is presented in a way that is easier to use, investors should suffer less information overload and be more likely to use it when making their asset allocation decisions.

Another potential source of information overload is the number of investment options offered in the plan. Research has shown that too many choices may hamper decision making. A study conducted by Iyengar and Lepper (2000) compared consumers' reactions to two displays of jam - one with six flavors, the other with twenty-four. While more consumers showed an interest in the larger display, it was the smaller display that elicited more purchases. This experiment demonstrated that consumers not only reduce the amount of processing when a task becomes overwhelming, but that they may, in fact, decide to withdraw from the task entirely.

Increasing the number of choices has also been shown to be related to investment behavior. For example, Iyengar, Jiang and Huberman (2003) find that increasing fund choice decreases 401(k) participation. Additionally, although not formerly tested, the high number of choices (over 500) offered to participants in Sweden's public pension private accounts might also explain the tendency for participants to opt for the investment 
default. In that plan, with the exception of the first year, over eighty percent of the eligible new participants invested according to the default option (Weaver 2002). While the number of choices in the Swedish system may seem extreme, the authors 403(b) plan offers over 285 investment choices across several vendors. One vendor alone offers 146 choices.

A third potential source of overload is the similarity of the options offered. As the number of funds that are offered grows, it is possible that the funds would be perceived to be more alike. For example, when participants can choose from multiple vendors (e.g., many university 403(b) plans), it is not unrealistic that the vendors would offer similar types of funds. Most likely a great deal of overlap will exist among the most popular fund types (e.g., index funds). As similarity in the funds increases, overload would also increase because funds are harder to differentiate from each other. If so, this would indicate that more distinct choice offerings are better.

Finally, the last factor we consider is a person's own financial knowledge. Consumer researchers have found that there exists an inverted U-shaped relationship between information search and knowledge-consumers with a moderate level of knowledge search the most before making a product choice (Bettman and Park, 1980). They have a basic understanding that allows them to interpret the information, but also, to realize the benefits associated with a more extensive search.0 Experts have no need to do an extensive search because they already know a great deal, and an extensive search would be redundant. Novices, who have very little knowledge, become overwhelmed by a choice task very quickly, so despite the fact that they would benefit the most from doing an extensive information search, they do not. Lacking the knowledge and 
experience to compare the available investment alternatives can make the whole process

even more intimidating, encouraging investors to look for an easy way out. In the case of defined contribution plans, the easy way out may be choosing the default or using some other choice heuristic. ${ }^{1}$ Thus, knowledge may be a critical individual difference that profoundly impacts a person's investment choices.

In summary, this paper focuses on four variables (display of information, number of choices, similarity among choices, and individual financial knowledge) that may impact feelings of overload, asset allocation and satisfaction with their investment decision. Experiment one manipulates the influence of information display and the number of choices. Experiment two manipulates the influence of the similarity of the options and the number of investment choices. Both experiments include a measure of financial knowledge.

\section{Experiment Participants and Financial Literacy}

\section{Experiment Participants}

Participants for both experiments were solicited during the summer months of 2003 at a mid-size public university in the Southeast. Campus mail, e-mail, and flyers were used to solicit participation. Participation was not limited to college employees, although the majority of participants were associated with the college. The study did attract several local tourists, parents of children attending camp on campus, and local construction workers. All participants were paid ten dollars in exchange for their assistance. In addition, each person was entered into a \$500 drawing held at the 
conclusion of the study. As a result, each experiment had a broad representation of the overall population.

The participants were randomly assigned to each experiment. Table 1 provides a description of each experiment's sample. The demographics of each sample were very similar suggesting that the randomization was successful. Both samples were predominantly female with a majority of the individuals greater than 30 years old. There was a broad representation of occupations, including professional administrators, professors, secretarial staff and maintenance workers. Salary and education levels were also well distributed.

\section{Financial Literacy}

In order to study the interaction between knowledge and the manipulated variables, each participant was given a ten question financial literacy exam during the experiment. The questions in the exam were taken directly from or adapted from questions asked in the John Hancock Financial Services Defined Contribution Plan Survey and financial literacy exams used by Wilcox (2003) and Dwyer, Gilkeson and List (2002).

Our results support prior findings that many investors lack even a basic understanding of financial concepts (John Hancock Financial Services, 2003). Each question in the ten point exam was worth one point. Table 2 reports the results of the exam. In both samples, the mean and median test scores are below fifty percent. In fact, more than one third of all participants answered two or less questions correctly.

Table 3 provides the questions and the percent of the combined sample that answered each question correctly. In the subsequent experiments, we use the mean of the 
test scores across all participants from both experiments as our indicator of average financial knowledge. Based on this average, we divided the individuals into two knowledge groups, high knowledge (above the mean) and low knowledge (below the mean). The distribution of test scores in both experiments was very similar.

The exam produced several surprising results. First, there was only one question that a majority of the individuals answered correctly. In total, eighty-four percent of the combined sample understood that they could lose money in the stock market. This is probably due to the publicity surrounding the end of the technology stock bubble. Unfortunately, a much lower percentage (43 percent) understood that they could lose money in the bond market. Only thirty-two percent of the sample knew the best time to transfer money into a long-term bond fund and twenty-two percent knew the definition of beta. Most people incorrectly answered the question regarding what types of investment securities are found in money market funds with only thirteen percent answering this question correctly. In fact, ten percent of the sample believed money market funds were riskier than equity funds.

We ran an ordinary least squares regression to determine the relationship between an individual's demographic characteristics and their test score. Results are presented in Table 4. The results show a significant relationship between gender and test score. Women scored one half point lower on the exam than men. Age also has a significant influence. The results suggest that younger participants know less than older participants. One explanation for this result is that as individuals age they gain financial experience which increases their financial literacy. Married individuals do better than their single counterparts. This may be because married individuals are more interested in finance out 
of concern for providing for their spouses if they should die. This interest translates into higher scores. This reasoning would also lead to expectations that people who have children would know more. However, people with children know less than their counterparts without children. Perhaps people who have larger families have less time to commit to educating themselves in finance.

One of the largest significant influences on the test score is related to salary. The omitted category in the regression is participants who earn $\$ 60,000$ or more. Relative to these highly paid individuals, those earning less tend to know less about financial matters. The test scores decline as the salary level declines, with those earning less than $\$ 20,000$ scoring 2.6 points lower than the highest salary group. Finally, education also plays an important role. The omitted category is participants with graduate degrees. Relative to the most educated individuals, individuals with less than a college degree perform the worst on the exam. Taken together, a single female in her twenties, in the lowest wage category with a high school or less education is expected to score 7.41 points lower on the exam than a married man over fifty with a graduate degree that earns more than $\$ 60,000$.

Table 5 examines the correlation between a person's perceived knowledge (what they think they know) and their actual financial literacy test score. ${ }^{2}$ The point of this analysis is to study whether the correlation is stronger for certain types of individuals. The results seem to suggest that this is true. There is a positive correlation of .77 for professors suggesting that these individuals "know what they know." On average, this group scored the highest on the exam and also accurately believes that they know more than others. Alternatively, the maintenance workers show a .17 correlation between their 
test score and their perceived knowledge. This suggests that this group may not have a good understanding of how little they actually know about investments. Similarly, those earning the highest salaries report a higher correlation than those earning the least (.55 vs .42). After reviewing the earlier regression results, it is not surprising that those earning the highest salaries perform the best on the exam and also perceive themselves to be more knowledgeable. The lowest correlation reported is for those with an education of high school or less (.10).

\section{Experiment One: Information Display (Table vs. Booklet) and Number of Investment Options (Low Number of Options vs. High Number of Options)}

\section{Method}

This experiment used a 2 (Display) X 2 (Number of Choices) X 2 (Knowledge) between subjects design. In the experiment, participants were asked to allocate a factitious $\$ 1,000$ in retirement savings among several mutual funds. They also were given the option to put the entire $\$ 1,000$ in a conservative default option (money market fund). To facilitate their decision making, they were given information regarding the performance of the asset choices based on eleven commonly reported attributes, including returns over various time periods, the standard deviation of the one year returns and the investment type. The reported statistics given to participants were actual performance measures from real funds and were obtained from Morningstar's website. The funds were divided into five factitious fund families. Each fund family offered at least one investment fund in each investment type. Table 6 summarizes the investment types and the reported statistics. The real names of the funds were changed to avoid biasing the results. Pretests were done on the fund family names to ensure that they did not have overly positive or negative attitudes associated with them. 
To manipulate the display of the information, fund choices were presented in either a table (low search cost) or booklet (high search cost). For both conditions, existing 403(b) plan information was used to develop the stimulus. For the low search cost condition (table), the assets choices were presented on one page in a standard spreadsheet format and organized by investment type. For the high search condition (booklet), the same exact information was presented for each asset but the fund options were presented in a booklet organized by fund family. Each page of the booklet was dedicated to one fund family and was not organized by investment type. This format produces higher search costs because participants must sort through multiple booklet pages in order to compare options within one investment type. This is similar to what a participant in a 403(b) would have to do when comparing offerings from different fund vendors.

The number of fund choices was the second source of manipulation. Participants were given either six funds (low number of choices) or sixty funds (high number of choices). ${ }^{3}$ Finally, as described in the previous section, individuals were divided into "high knowledge" and "low knowledge" categories based on their financial knowledge test scores.

Once the allocation decision was made, participants were asked to complete measures on their information overload and choice satisfaction. Table 7 reports the questions in these measures and their reliability. In addition, questions regarding the participants' confidence in their choices and perceived quality of their decision were included to determine investor's perceptions of their ability to make good investment decisions. 


\section{Results}

Table 8 Panel A reports the cell means for the overload measure. Using a three factor analysis of variance, we found two significant main effects. As expected, there was a significant difference in measured overload between the two knowledge categories $(\mathrm{F}(1,186)=20.54, \mathrm{p}<.01) .{ }^{4}$ Individuals with less than average knowledge were significantly more overwhelmed than those with above average knowledge. In addition, individuals presented with more choices experienced greater overload $(\mathrm{F}(1,186)=5.11$, $\mathrm{p}<.05)$. This supports the notion that as the number of alternatives increases, participants begin to experience information overload. A main effect related to the display condition (booklet vs. table) was not found.

Two significant interaction effects were found suggesting that how individuals react to changes in the number of options $(F(1,186)=2.71, p<.10)$ or how the information is displayed $(\mathrm{F}(1,186)=7.19, \mathrm{p}<.01)$ depends on their relative knowledge. Figure 1 displays the results graphically. In the leftmost graph, individuals with below average knowledge are overwhelmed regardless of the number of choices they are given. This is confirmed statistically with Scheffe multiple-comparison tests. A statistical difference in experienced overload is not found between the high choice and low choice conditions for individuals with below average knowledge. Interestingly, the number of choices does have an impact on the reported overload for individuals with above average knowledge. These individuals experience statistically greater feelings of overload with more choices $(\mathrm{p}<.10) .{ }^{5}$ This is an important finding because it indicates that while a change in plan design, like decreasing the number of choices, may reduce information overload, it may only be effective for some participants. In this case, it only helps those with above 
average knowledge and does nothing for a very vulnerable group, those with below average knowledge. Another striking result is that individuals with above average knowledge and few investment options are significantly less overloaded than below average knowledge participants in either context ( $\mathrm{p}<.01$ in both cases).

The second significant interaction effect is between knowledge and the display condition. Individuals with above average knowledge who were given the table format were significantly less overloaded than the below average knowledge individuals given either format $(\mathrm{p}<.01$ in both cases). However, there are no differences in the overload measure of the high knowledge participants in the booklet condition and the low knowledge participants in either format. In addition, manipulating the display does nothing to attenuate the low knowledge or high knowledge participants' feelings of overload.

We also investigated reported feelings of satisfaction. In this case, there were only two significant main effects and no interactions. Table 8, Panel B reports the means. Individuals with above average knowledge were more satisfied with their decision than individuals with below average knowledge $(\mathrm{F}(1,189)=6.82, \mathrm{p}<.01)$. Individuals receiving the table format were also more satisfied with their decision $(F(1,189)=3.11, p<.10)$.

Focusing on the actual asset allocation, we coded an indicator variable that was set equal to one if the participant chose the default option and zero if they chose a nondefault allocation. The cell means of this variable equate to the percentage of individuals in each cell that opted for the default. The results are reported in Table 8, Panel C. Once again the influence of knowledge is significant. Twenty percent of the low knowledge 
individuals chose the default option compared to two percent of the high knowledge individuals $(\mathrm{F}(1,190)=14.41, \mathrm{p}<.01)$. There were no other significant main effects.

A significant interaction is found between knowledge and the number of choices $(\mathrm{F}(1,190)=6.04, \mathrm{p}<.05)$ (See Figure 2). High knowledge individuals do show an increase in the mean default rate when the number of choices increases. This is what we expected given that they were shown earlier to experience significantly greater overload with an increase in the number of choices. However the difference in default means is not significant. Contrary to our expectations, there was a significant difference between default means and the number of choices for low knowledge individuals. Given that the low knowledge individuals experienced an insignificant difference in overload, we expected that the same insignificant difference in default would exist. Interestingly, as the number of choices increase individuals with low knowledge invest less in the default option. According to the Scheffe multiple-comparison tests, the difference is significant $(\mathrm{p}<.05)$.

\section{Discussion}

Together these results suggest a strong mediating effect of knowledge. Feelings of information overload experienced by individuals with below average knowledge are unaffected by changes in the number of options offered or the display type. For these individuals, changing the number of investment options does nothing to relieve their overload. On the other hand, reducing the number of options does reduce information overload for individuals with above average knowledge. Above average knowledge individuals are also more satisfied with their decision. 
Turning to the actual asset allocation decision, significantly fewer individuals with high knowledge chose the default option compared to their below average counterparts. However, low knowledge participants were less likely to choose the default when given more choice. This result is inconclusive and requires further investigation. While these participants reported feeling overwhelmed, we expect that they would "shut down" their decision making in some way. Obviously they are not doing this through selection of the default. However, they may be using another heuristic that has not been captured in this study.

To examine this further, we looked more closely at the sample of individuals in the high choice context who chose not to allocate 100 percent of their money to the default option. Our hypothesis is that the default still has an influence on investment choices even when participants do not choose to allocate their entire investments to the fund. If this is so and assuming everything else is equal, we would expect the default option to be chosen more often as a fund in the investors' overall portfolio. In particular, we expect low knowledge individuals to be influenced the most.

In order to investigate this, we limit ourselves to those individuals who have chosen to invest in at least one money market fund. We do this because we assume that when individuals make their portfolio decisions, they first decide on how much they will allocate to money market funds and then select the fund from their available choices. We designed the default option so that an individual would have no clear reason to choose the default money market fund over other money markets. The default option was not the dominant fund based on the reported performance statistics (i.e., historical returns and 7day yield). In addition, the default fund we presented did not offer a fee advantage over 
any other funds. In fact, all the money market funds reported the same expense ratio. Finally, we eliminated the role primacy and recency effects could play by listing the default option fourth (out of five possible choices) on the allocation form. Despite the design, 20 out of a possible 43 individuals chose to invest in the default fund. This is twice the number that invested in the second most popular fund, which was the dominant fund in terms of historical returns and yield.

Finally, we broke down the individuals by knowledge. In most cases, the numbers of low knowledge individuals and high knowledge individuals investing in each money market fund were equal. Interestingly, it was only in the case of the default fund that the number of low knowledge individuals invested in the money market fund was much greater than the high knowledge individuals (13 individuals versus 7 individuals). While these results cannot be tested for statistical significance, they do suggest that the default option may play a larger role than we expected in allocation decisions and this role may be greater for low knowledge individuals. This is an interesting area for future research.

\section{Experiment Two: Similarity, Number of Options and Knowledge}

This experiment used a 2 (Similarity) X 2 (Number of Choices) X 2 (Knowledge) between subjects design. As in experiment one, individuals were asked to allocate a factitious $\$ 1,000$ in retirement savings among several asset choices or in a default option. Individuals in this experiment were given the same information about the investment options as in experiment one. All of the investment information was presented in the low search cost table format.

In this experiment the similarity of the options offered was manipulated, as was the number of options offered (6 or 60). Participants were given options that were either 
highly similar or very distinct. The distinct options were the same options offered in experiment one. Specifically, similar options were found by choosing funds that were listed under the same Morningstar category, had comparable investment strategies and similar performance. ${ }^{6}$ For example, the high information/low similarity condition included sixty fund options which included five money market funds, five bond funds and fifty equity funds. The fifty equity funds included five different equity index funds, fifteen different growth funds, fifteen different blended funds and fifteen different value funds. In contrast, the high information/high similarity option included the same number of fund choices but only one money market fund and one bond index fund were offered. The remaining choices were made from fifty-eight equity index funds. This is admittedly extreme. Even in the case where multiple vendors might offer similar funds, it is unlikely that this many index funds would be offered. However, the advantage of this design is that if similarity is not a significant factor in this extreme case, we can conclude that it will not be a factor in less extreme and more realistic cases. ${ }^{7}$

Results

As in the first experiment, knowledge plays a large role in the individuals' level of overload and their satisfaction with their decision. Table 9 reports the cell means. Using a three factor analysis of variance, we find that information overload is significantly higher for individuals with low knowledge $(F(1,190)=37.54, \mathrm{p}<.01)$. In addition, information overload increases with the number of choices offered $(\mathrm{F}(1,190)=13.93, \mathrm{p}<.01)$. There are no significant interaction effects in this experiment. Satisfaction remains statistically higher for individuals with above average knowledge $(\mathrm{F}(1,187)=13.80, \mathrm{p}<.01)$. In addition, individuals are more satisfied with their 
decision when they are given more distinct choices $(F(1,187)=9.69, \mathrm{p}<.01)$. A decreased number of choices also results in higher satisfaction $(F(1,187)=6.67, p<.05)$. No significant interaction effects were found.

As in experiment one, individuals with above average knowledge chose the default option less often $(\mathrm{F}(1,192)=19.34, \mathrm{p}<.01)$. However, in this case, there is also a three-way interaction between similarity, information and knowledge $(\mathrm{F}(1,192)=4.57$, $\mathrm{p}<.05$ ). Figure 3 displays the results. It appears that for high knowledge individuals, the default option is chosen more frequently when more funds are offered and the funds are more similar. This supports the notion that people become more overloaded as alternatives are harder to differentiate. For the low knowledge individuals, the reaction to the number of choices depends on the similarity of the options. When the choices are large, increasing similarity does increase the number choosing the default. However, when the choices are small, increasing the similarity has the opposite effect.

\section{Discussion}

Supporting the results from experiment one, relative investor knowledge played a key role in reported overload, satisfaction and whether an individual chose the default option or not. While the similarity of the options did not contribute to reported feelings of overload, the options similarity did have some influence on satisfaction and asset allocation. Once again, the investment patterns of the individuals with low knowledge were unusual and unexpected. The lack of predictability in their investment choices may be a result of their high level of overload. This again highlights the importance of investors' knowledge. 


\section{Conclusions}

This study contributes to literature on retirement plan design by examining three common differences among defined contribution plans that can lead to varying degrees of overload and satisfaction. In addition, these features can influence the participants' probability of choosing the default option. The three plan features are the investment information display, the number of investment choices and the similarity of the investment choices. One of the most important features of this study is that it incorporates the relative level of each individual's financial knowledge into the analysis. It is this knowledge factor that is most pivotal to our findings.

Our findings do show that changes to plan design can help some individuals. We find individuals with above average financial knowledge do report significantly less overload when given fewer investment choices, which confirms previous research that plan design is important.

Also, our findings suggest individuals with below average knowledge find the investment decision overwhelming regardless of the plan features. Altering the plan by offering investment information in a more easily comparable format or by reducing the choices offered does not attenuate the low knowledge individuals' feelings of overload. Thus in addition to improving plan design, plan sponsors should also consider improving financial education, especially for participants with below average financial knowledge. However, whether improving an individual's financial knowledge can reduce his subsequent feelings of overload when making financial decisions remains to be tested. 
The importance of financial education is not new to policymakers. Alan Greenspan (2002) recently made a statement that “...education can play a critical role by equipping consumers with the knowledge required to make wise decisions when choosing among the myriad of financial products and providers." Research into the success of financial education efforts is limited but does show promise (see, e.g., Clark, d'Ambrosio, McDermed, Sawant 2003). Our results show that sponsors must not only devise successful educational programs for participants but be aware that those individuals who need the education the most have the weakest perception of their own relative knowledge. The downside of this is that these individuals might not know they need assistance and therefore may not pursue opportunities to educate themselves. Furthermore, plan sponsors must realize that printed educational material might be ineffective because even in our small sample we had several participants who had difficulty reading the survey. Thus, plan sponsors face a daunting task to educate these vulnerable participants.

Our results also show that knowledge plays a large role in who opts for the default. We find that low knowledge individuals are opting for the default allocation more often than high knowledge individuals. In experiment one, twenty percent of the low knowledge participants chose the default compared to two percent of the high knowledge individuals. The results were even more striking in experiment two (twenty five percent vs four percent). The often conservative nature of common default investments leads to concerns that individuals invested in these assets will have inadequate retirement savings. This concern is compounded by the fact that new evidence suggests that the same individuals who tested the lowest on our financial exam are the 
same types of individuals who are not saving enough for retirement. The Employee Benefit Research Institute (EBRI) study finds that most older, low-income single women will not have sufficient retirement savings in the future to cover basic expenditures and health care assistance (EBRI 2003). According to this study, some demographic groups can salvage their retirement savings by increasing savings today, but the additional savings required of this group is unrealistic. Thus, for this group with limited savings the investment decision becomes even more critical. As a result, their only opportunity to secure their retirement is to make investment decisions that result in above-average returns. Unfortunately, investment in a conservative default vehicle eliminates the possibility of above-average returns and assures their insufficient savings.

So what can a plan sponsor do? One option is for plan sponsors to offer financial assistance to participants. Services such as Financial Engines $\mathbb{C}$ or those offering personal financial planners to participants are already available in some 401(k) plans. Similarly, increasing financial education efforts may promote more active choice. However, bear in mind the tried and true adage "You can lead a horse to water, but you can't make him drink." Despite all efforts, a subset of participants will always choose not to make a decision. As a result, plans sponsors must focus on plan design, particularly plan defaults. The results of this paper supports the move by some plan sponsors away from offering "one size fits all" defaults. All of these suggestions directly apply to Social Security if private accounts are introduced.

In closing, the lack of financial knowledge in our sample raises concerns about the public's ability to effectively manage their retirement accounts. Concerns that must be addressed before private Social Security accounts are introduced. As a result, more 
research into ways to design plans to promote sound decision making, methods for improving the presentation of investment information and making it more easy to use and techniques for effectively educating individuals in finance is needed. 


\section{References}

Agnew, J. (2003). Inefficient Choices in 401(k) Plans: Evidence from Individual Level Data. Manuscript in preparation, The College of William and Mary.

Benartzi, S., \& Thaler, R. (2001). Naive Diversification Strategies in Retirement Saving Plans. American Economic Review, 91(1), 79-98.

Benartzi, S. (2001). Excessive Extrapolation and the Allocation of 401(k) Accounts to Company Stock? Journal of Finance, 56 (5), 1747-1764.

Bettman, J. R. \& C. Whan Park, 1980. Effects of Prior Knowledge and Experience and Phase of the Choice Process on Consumer Decision Processes: A Protocol Analysis. Journal of Consumer Research 7, (December), 234-248.

Choi, J., Laibson, D., Madrian, B. \& Metrick, A. (2002). Defined Contribution Pensions: Plan Rules, Participant Decisions, and the Path of Least Resistance. In James M. Poterba (Ed.), Tax Policy and the Economy,(Vol. 16, pp. 67-113). Cambridge, MA: MIT Press

Choi, J., Laibson, D., Madrian B., \& Metrick, A. (2003). Active Decisions: A Natural Experiment in Savings. Manuscript in preparation, Harvard University.

Choi, J., Laibson, D., Madrian, B. \& Metrick, A. For Better or For Worse: Default Effects and 401(k) Savings Behavior. Perspectives in the Economics of Aging, David Wise ed., forthcoming.

Clark, R., d'Ambrosio, M., McDermed, A., \& Sawant, K. (2003). Sex Differences, Financial Education, and Retirement Goals. Manuscript in preparation, The Wharton School, Pension Research Council.

Dwyer, P., Gilkeson, J., \& List, J. (2002). Gender Differences in Revealed 
Risk Taking: Evidence from Mutual Fund Investors. Economic Letters, 76(2), 151-159.

EBRI Online, January 2003. Private Pension Plans, Participation, and Assets: Update. from http://www.ebri.org/facts/0103fact.htm

John Hancock Financial Services. (2002). Insight into Participant Investment, Knowledge and Behavior. Eighth Defined Contribution Survey.

Greenspan, Alan, 2002. "Prepared Statement." Hearings on the State of Financial Literacy and Education in America. U.S. Senate Committee on Banking, Housing and Urban Affairs, February 6.

Ippolito, P. \& Mathios, A.D. (1990). Information, Advertising and Health Choice: A Study of the Cereal Market. RAND Journal of Economics, 21(3), $459-480$.

Ippolito, P. \& Mathios, A.D. (1994). Information, Policy, and the Sources of Fat and Cholesterol in the U. S. Diet. Journal of Public Policy and Marketing $13(2), 200-217$.

Iyengar, S., Jiang,W. \& Huberman, G. (2003). How Much Choice is Too Much?: Contributions to 401(k) Retirement Plans. Working Paper 2003-10, The Wharton School. Pension Research Council.

Iyengar, S., \& Lepper, M. (2000). When Choice is Demotivating: Can One Desire Too Much of a Good Thing? Journal of Personality and Social Psychology, 76, 995-1006. 
Madrian, B. \& Shea, D. (2001). The Power of Suggestion: Inertia in 401(k) Participation and Savings Behavior. Quarterly Journal of Economics, 116(4), $1149-1165$.

Moorman, C. (1990). The Effects of Stimulus and Consumer Characteristics on the Utilization of Nutrition Information. Journal of Consumer Research, 17(December), 362-374.

Moorman, C. (1996). A Quasi Experiment to Assess The Consumer And Informational Determinants of Nutrition Information Processing Activities: The Case of the Nutrition Labeling and Education Act. Journal of Public Policy and Marketing, 15(1), 28-44.

Muller, T. (1985). Structural Information Factors Which Stimulate the Use of Nutrition Information: A Field Experiment. Journal of Marketing Research, 22(May), 143-157.

Munnell, A. H. \& Sundén, A. (2004). Coming Up Short: The Challenge of 401(k) Plans. The Brookings Institution Press.

Munnell, A. H., Sundén, A. \& Taylor, C. (2001/2002). What Determines 401(k) Participation and Contributions? Social Security Bulletin, 64 (3), 64-76.

Nelson, P. (1970). Information and Consumer Behavior. Journal of Political Economy, 78(March/April), 311-329.

Nelson, P. (1974). Advertising as Information. Journal of Political Economy, 83 (July/August), 729-754.

Payne, J.W., Bettman, J.R. \& Johnson, E.J. (1988). Adaptive Strategy Selection in 
Decision Making. Journal of Experimental Psychology: Learning, Memory, and Cognition, 14 (3), 534-552.

Payne, J. W., Bettman, J.R. \& Luce, M.F. (1996). When Time is Money: Decision Behavior under Opportunity-Cost Time Pressure. Organizational Behavior and Human Decision Processes, 66(2), 131-152.

Roe, B., Levy, A.S. \& Derby, B.M. (1999). The Impact of Health Claims on Consumer Search and Product Evaluation Outcomes: Results from FDA Experimental Data. Journal of Public Policy and Marketing, 18(Spring), 89-105.

Stigler, G. (1961). The Economics of Information. Journal of Political Economy 69(June), 213-255.

Thaler, R., \& Benartzi, S. (2004). Save More Tomorrow: Using Behavioral Economics to Increase Employee Savings. Journal of Political Economy, 112, No. S1 (February), S164-S187.

Weaver, K. May 30-31, 2002. "Reforming Social Security: Lessons From Abroad.” Conference Proceeding from Retirement Research Consortium's Fourth Annual Conference.

Wilcox, R. T. (2003). Bargain Hunting or Star Gazing? Investors' Preferences for Stock Mutual Funds. Journal of Business, 76(4), 645-655. 


\section{Endnotes}

${ }^{1}$ For example, participants following the $1 / \mathrm{n}$ heuristic opt to divide their contribution allocations evenly among the fund options offered. While this strategy can result in a well-diversified portfolio, Benartzi and Thaler (2001) have shown that it can also lead to large ex-ante welfare losses. Agnew (2003) finds that those with relatively low salaries are most likely to follow the $1 / \mathrm{n}$ heuristic. In this case, salary may be proxying for financial knowledge.

${ }^{2}$ During the experiment, individuals answered the following question: "How do you rate your knowledge of retirement investments relative to other people?" Individuals answered using a scale from one (much less knowledge) to ten (a great deal more knowledge) to answer this question. We use their answers as a measure of how much they think they know.

${ }^{3}$ Pretests were done to determine the number of funds that were considered "low" vs "high."

${ }^{4}$ Consistent with the marketing literature, we report the F statistic estimated from the ANOVA analysis related to the variable being discussed. Degrees of freedom are reported within the parentheses. In this example, the F statistic is 20.54 for the knowledge variable. The $\mathrm{p}<.01$ indicates the significance level is less than .01 .

${ }^{5}$ The p-values reported in all of the discussions of the interaction variables are based on the Scheffe-adjusted significance levels. In this case, the Scheffe-adjusted significance level is less than .10 .

${ }^{6}$ Similarity between funds was confirmed through pretests.

${ }^{7}$ In this experiment, responses for the low similarity cells were taken from the responses of participants in experiment one's table format cells. 
Table 1. Description of Samples

This table provides a description of the participants in each experiment based on demographic variables.

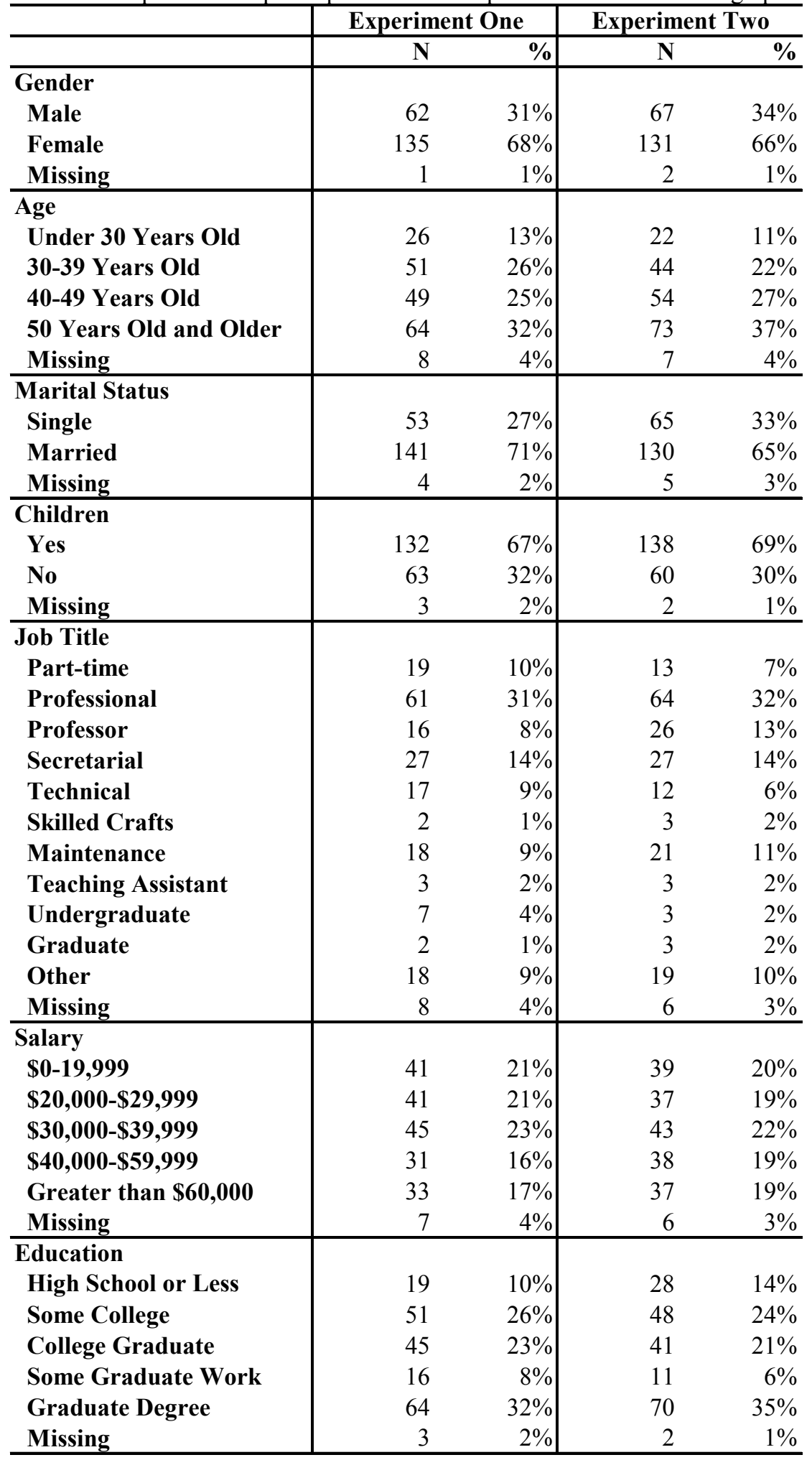


Table 2. Summary of Test Scores

Participants in each experiment were given a written test to assess their financial literacy. The test was comprised of ten questions worth one point each. The table below summarizes the participants' performance in each experiment.

\begin{tabular}{c|ccc|ccc}
\hline & \multicolumn{3}{|c|}{ Experiment One } & \multicolumn{3}{c}{ Experiment Two } \\
\hline Test Score & N & \% & Cum. \% & N & \% & Cum. \% \\
\hline $\mathbf{0}$ & 13 & $7 \%$ & $7 \%$ & 9 & $5 \%$ & $5 \%$ \\
$\mathbf{1}$ & 19 & $10 \%$ & $16 \%$ & 24 & $12 \%$ & $17 \%$ \\
$\mathbf{2}$ & 38 & $19 \%$ & $35 \%$ & 39 & $20 \%$ & $36 \%$ \\
$\mathbf{3}$ & 39 & $20 \%$ & $55 \%$ & 28 & $14 \%$ & $50 \%$ \\
$\mathbf{4}$ & 29 & $15 \%$ & $70 \%$ & 30 & $15 \%$ & $65 \%$ \\
$\mathbf{5}$ & 14 & $7 \%$ & $77 \%$ & 20 & $10 \%$ & $75 \%$ \\
$\mathbf{6}$ & 14 & $7 \%$ & $84 \%$ & 20 & $10 \%$ & $85 \%$ \\
$\mathbf{7}$ & 12 & $6 \%$ & $90 \%$ & 11 & $6 \%$ & $91 \%$ \\
$\mathbf{8}$ & 9 & $5 \%$ & $94 \%$ & 8 & $4 \%$ & $95 \%$ \\
$\mathbf{9}$ & 10 & $5 \%$ & $99 \%$ & 9 & $5 \%$ & $99 \%$ \\
$\mathbf{1 0}$ & 1 & $1 \%$ & $100 \%$ & 2 & $1 \%$ & $100 \%$ \\
\hline Total & 198 & \multicolumn{3}{|c|}{} \\
\hline Mean & \multicolumn{7}{|c|}{3.73} & 200 & 3.84 \\
Median & 3.00 & & \\
\hline
\end{tabular}


Table 3. Summary of Test Questions

Below are the ten questions given on the financial literacy exam. For each question, the percent of the total participants from both experiments who answer the question correctly is provided.

\section{Percent of Combined Sample Who Answered Each Question Correctly}

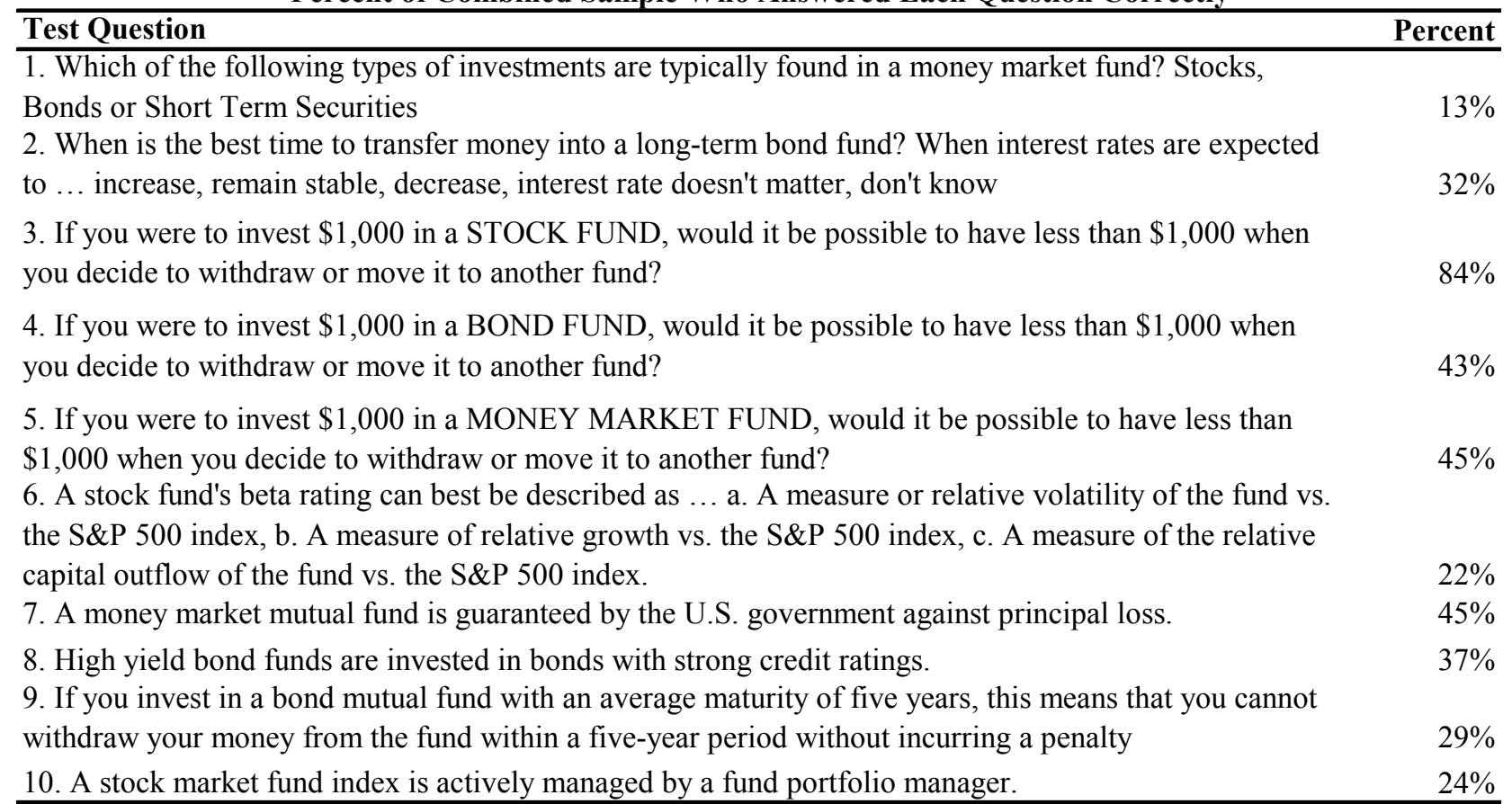


Table 4. Financial Literacy Regression

This table presents the results of an ordinary least squares regression. The dependent variable is the financial literacy test score earned by each participant. "Female" is a dummy variable equal to one if the participant is female, zero otherwise. "Under 30 Years Old", "30-39 Years Old" and "40-49 Years Old" are dummy variables equal to one if the participant falls in that age range. The omitted age range is 50 years and older. "Married" is a dummy variable equal to one if the participant is married. "Children" is a dummy variable equal to one if the participant has children. " $\$ 0-\$ 19,999 "$, " $\$ 20,000-\$ 29,999 "$ " " $\$ 30,000-\$ 39,999 "$ ", " $\$ 40,000-\$ 59,999$ " are dummy variables that refer to the participant's annual salary. The omitted salary range is "Equal to or Greater than $\$ 60,000 "$ ". "High School or Less", "Some College", "College Graduate" and "Some Graduate Work" are dummy variables referring to the participant's highest level of education. The omitted dummy variable is "Graduate Degree". P-values are based on robust standard errors that are adjusted for heteroskedacity. *** indicates significance at the $1 \%$ level. ** indicates significance at the $5 \%$ level. * indicates significance at the $10 \%$ level.

\begin{tabular}{|c|c|c|}
\hline \multicolumn{3}{|c|}{ Dependent Variable: Test Score } \\
\hline & Coefficent & P-Value \\
\hline Constant & 7.1675 & $0.000 * * *$ \\
\hline Female & -0.4456 & $0.085 *$ \\
\hline Under 30 Years Old & -1.5968 & $0.001 * * *$ \\
\hline 30-39 Years Old & -0.9387 & $0.006 * * *$ \\
\hline 40-49 Years Old & -0.7953 & $0.007 * * *$ \\
\hline Married & 0.6081 & $0.019 * *$ \\
\hline Children & -0.8379 & $0.010 * *$ \\
\hline \$0-19,999 & -2.6317 & $0.000 * * *$ \\
\hline$\$ 20,000-\$ 29,999$ & -2.3217 & $0.000 * * *$ \\
\hline$\$ 30,000-\$ 39,999$ & -2.0273 & $0.000 * * *$ \\
\hline$\$ 40,000-\$ 59,999$ & -1.4631 & $0.002 * * *$ \\
\hline High School or Less & -2.1285 & $0.000 * * *$ \\
\hline Some College & -0.9431 & $0.011 * *$ \\
\hline College Graduate & 0.0986 & 0.802 \\
\hline Some Graduate Work & -0.5906 & 0.247 \\
\hline Number of Observations & 274 & \\
\hline R-Squared & 0.42 & \\
\hline
\end{tabular}


Table 5. Correlation between Test Score and Personal Perception of Relative Knowledge

This table reports the correlation between the participants' financial literacy test score and their own perception of their relative financial knowledge. The relative financial knowledge measure is derived from the participant's answer to a survey question. In both experiments, each participant was asked to rate his knowledge of retirement investments relative to other people on a scale from one to ten (one- much less knowledge than others, ten- great deal more knowledge than others.) The median test score and knowledge "confidence" level are reported below.

\begin{tabular}{l|cccc}
\hline & & & Median Test & $\begin{array}{c}\text { Median } \\
\text { Confidence }\end{array}$ \\
\hline Job Title & N & Correlation & & \\
Part-time & 25 & 0.61 & 2.0 & 5.0 \\
Professional & 99 & 0.49 & 4.0 & 6.0 \\
Professor & 31 & 0.77 & 6.0 & 7.0 \\
Secretarial & 36 & 0.56 & 3.0 & 3.0 \\
Technical & 22 & 0.35 & 3.0 & 6.0 \\
Maintenance & 26 & 0.17 & 2.5 & 4.0 \\
Teaching Assistant & 4 & 0.54 & 2.0 & 4.5 \\
Undergraduate & 8 & 0.41 & 2.0 & 3.0 \\
Graduate & 5 & 0.78 & 2.0 & 4.0 \\
Other & 26 & 0.26 & 3.0 & 4.5 \\
\hline Salary & & & & \\
\$0-19,999 & 59 & 0.42 & 2.0 & 4.0 \\
\$20,000-\$29,999 & 57 & 0.38 & 3.0 & 3.0 \\
\$30,000-\$39,999 & 68 & 0.49 & 4.0 & 5.0 \\
\$40,000-\$59,999 & 52 & 0.45 & 4.0 & 6.0 \\
Greater than \$60,000 & 47 & 0.55 & 7.0 & 7.0 \\
\hline Education & & & \\
High School or Less & 34 & 0.10 & 1.0 & 3.0 \\
Some College & 73 & 0.45 & 2.0 & 4.0 \\
College Graduate & 65 & 0.60 & 4.0 & 5.0 \\
Some Graduate Work & 19 & 0.71 & 4.0 & 6.0 \\
Graduate Degree & 98 & 0.59 & 5.0 & \\
\hline
\end{tabular}




\section{Table 6. Investment Types and Reported Financial Attributes}

\section{Panel A. Investment Types}

1. Money Market Funds

2. Bond Index Funds

3. Equity Index Funds

4. Equity Growth Funds

5. Equity Blended Funds

6. Equity Value Funds

\section{Panel B. Reported Financial Attributes}

1. Investment Type

2. Year-to-Date Return (\%)

3. One Year Return (\%)

4. Three Year Return(\%)

5. Five Year Return

6. Expense Ratio (\%)

7. Net Assets (\$ Millions)

8. Risk (Standard Deviation of One Year Returns)

9. Analyst Risk Description (Relative to Other Funds in Investment Type: Low, Below Average, Average, Above Average, High)

10. Manager Tenure (Years)

11. 7-day Yield (\%) (Only Reported for Money Market Funds) 


\section{Table 7. Composition of Overload and Satisfaction Measures}

\section{Panel A. Overload Measure}

1. There were too many different options to consider (Scale 1 to 6, Strongly Disagree to Strongly Agree)

2. This decision required a great deal of thought (Scale 1 to 6, Strong Disagree to Strongly Agree)

3. This was a difficult decision (Scale 1 to 6, Strong Disagree to Strongly Agree)

4. I found this decision to be overwhelming (Scale 1 to 6, Strong Disagree to Strongly Agree)

5. It was difficult to comprehend all of the information available to me (Scale 1 to 6, Strong Disagree to Strongly Agree)

6. This task was stressful (Scale 1 to 6, Strong Disagree to Strongly Agree)

7. It was a relief to make a decision (Scale 1 to 6, Strong Disagree to Strongly Agree)

Standardized item alpha

\section{Panel B. Satisfaction Measure}

1. How satisfied are you with your allocation decision (Scale 1 to 7, Very Dissatisfied to Very Satisfied)

2. How certain are you that you made the best allocation decision (Scale 1 to 7, Very Uncertain to Very Certain)

3. How confused did you feel while performing the task (Scale 1 to 7, Very Confused to Not at all Confused)

4. How likely is it that you did not make the best allocation decision (reversed scored) (Scale 1 to 7, Very Unlikely to Very Likely)

5. How likely is it that some of the funds that you did not choose would be equal to or better than the ones that you did select (reverse scored) (Scale 1 to 7, Very Unlikely to Very Likely) 
Table 8. Experiment One- Cell Means The following tables present the cell means for the display experiment. The number of participants in each cell is in parentheses. $* * *$ indicates significance at the $1 \%$ level. $* *$ indicates significance at the $5 \%$ level. $*$ indicates significance at the $10 \%$ level.

Panel A. Mean of Overload Measure

\begin{tabular}{|c|c|c|c|c|c|}
\hline & \multicolumn{2}{|c|}{ Table } & \multicolumn{2}{|c|}{ Booklet } & \multirow{2}{*}{$\begin{array}{l}\text { Knowledge } \\
\text { Type Mean: }\end{array}$} \\
\hline & Low Number of Choices & High Number of Choices & Low Number of Choices & High Number of Choices & \\
\hline Low Knowledge & $27.10(30)$ & $28.83(23)$ & $26.52(27)$ & $25.96(26)$ & $27.05^{\star \star *}(106)$ \\
\hline High Knowledge & $19.09(22)$ & $23.12(26)$ & $22.78(18)$ & $26.18(22)$ & $22.81^{\star * \star} \quad(88)$ \\
\hline All & $23.71(52)$ & $25.80(49)$ & $25.02(45)$ & $26.06(48)$ & \\
\hline Display Type Mean & 24.7 & $2(101)$ & 25. & $6(93)$ & \\
\hline & $\begin{array}{l}\text { Low Number } \\
\text { High Number }\end{array}$ & $\begin{array}{l}\text { f Choices Mean: } \\
\text { f Choices Mean: }\end{array}$ & $\begin{array}{l}24.32^{* *}(97) \\
25.93^{* *}(97)\end{array}$ & & \\
\hline
\end{tabular}

Panel B. Mean of Satisfaction Measure

\begin{tabular}{|l|c|c|c|c|}
\hline & \multicolumn{2}{|c|}{ Table } & \multicolumn{2}{c|}{ Booklet } \\
\hline & Low Number of Choices & High Number of Choices & Low Number of Choices & High Number of Choices \\
\hline & $20.16(32)$ & $18.43(23)$ & $19.07(28)$ & $18.16(25)$ \\
\hline Low Knowledge Mean:
\end{tabular}

Panel C. Mean of Default Measure

\begin{tabular}{|c|c|c|c|c|c|}
\hline & \multicolumn{2}{|c|}{ Table } & \multicolumn{2}{|c|}{ Booklet } & \multirow{2}{*}{\begin{tabular}{|l|} 
Knowledge \\
Type Mean:
\end{tabular}} \\
\hline & Low Number of Choices & High Number of Choices & Low Number of Choices & High Number of Choices & \\
\hline Low Knowledge & $0.31(32)$ & $0.09(23)$ & $0.25(28)$ & $0.12(26)$ & $0.20^{* \star *}(109)$ \\
\hline High Knowledge & $0.00(22)$ & $0.04(26)$ & $0.00(18)$ & $0.04(23)$ & $0.02^{* * *}(89)$ \\
\hline All & $0.19(54)$ & $0.06(49)$ & $0.15(46)$ & $0.08(49)$ & \\
\hline Display Type Mean: & \multicolumn{2}{|c|}{$0.13(103)$} & \multicolumn{2}{|c|}{$0.12(95)$} & \\
\hline & $\begin{array}{l}\text { Low Number } \\
\text { High Number }\end{array}$ & $\begin{array}{l}\text { Choices Mean: } \\
\text { f Choices Mean: }\end{array}$ & $\begin{array}{l}0.17(100) \\
0.07(98)\end{array}$ & & \\
\hline
\end{tabular}


Table 9. Experiment Two- Cell Means The following tables present the cell means for the display experiment. The number of participants in each cell is in parentheses. ${ }^{* * *}$ indicates significance at the $1 \%$ level. $* *$ indicates significance at the $5 \%$ level. $*$ indicates significance at the $10 \%$ level.

\section{Panel A. Mean of Overload Measure}

\begin{tabular}{|c|c|c|c|c|c|}
\hline & \multicolumn{2}{|c|}{ Low Similarity } & \multicolumn{2}{|c|}{ High Similarity } & \multirow{2}{*}{$\begin{array}{l}\text { Knowledge } \\
\text { Type Mean: }\end{array}$} \\
\hline & Low Number of Choices & High Number of Choices & Low Number of Choices & High Number of Choices & \\
\hline Low Knowledge & $27.10(30)$ & $28.83(23)$ & $24.50(24)$ & $29.00(21)$ & \multirow{5}{*}{$\begin{array}{l}27.28^{* * *}(98) \\
21.66^{* * \star}(100\end{array}$} \\
\hline High Knowledge & $19.09(22)$ & $23.12(26)$ & $19.83(24)$ & $23.89(28)$ & \\
\hline All & $23.71(52)$ & $25.80(49)$ & $22.17(48)$ & $26.08(49)$ & \\
\hline Similarity Mean: & \multicolumn{2}{|c|}{$24.72(101)$} & \multicolumn{2}{|c|}{$24.14(97)$} & \\
\hline & $\begin{array}{l}\text { Low Number } \\
\text { High Number }\end{array}$ & $\begin{array}{l}\text { f Choices Mean: } \\
\text { ff Choices Mean: }\end{array}$ & $\begin{array}{l}22.97^{* * *}(100) \\
25.94^{* * *}(98) \\
\end{array}$ & & \\
\hline
\end{tabular}

Panel B. Mean of Satisfaction Measure

\begin{tabular}{|c|c|c|c|c|c|}
\hline & \multicolumn{2}{|c|}{ Low Similarity } & \multicolumn{2}{|c|}{ High Similarity } & \multirow{2}{*}{$\begin{array}{l}\text { Knowledge } \\
\text { Type Mean: }\end{array}$} \\
\hline & Low Number of Choices & High Number of Choices & Low Number of Choices & High Number of Choices & \\
\hline Low Knowledge & $20.16(32)$ & $18.43(23)$ & $18.46(24)$ & $15.60(20)$ & $18.42^{* * *}(99)$ \\
\hline High Knowledge & $22.36(22)$ & $21.50(26)$ & $20.71(21)$ & $18.74(27)$ & $20.75^{\star \star *}(96)$ \\
\hline All & $21.06(54)$ & $20.06(49)$ & $19.51(45)$ & $17.40(47)$ & \\
\hline Similarity Mean: & \multicolumn{2}{|c|}{$20.58^{* * *}(103)$} & \multicolumn{2}{|c|}{$18.43^{\star * \star}(92)$} & \\
\hline & $\begin{array}{l}\text { Low Number } \\
\text { High Number }\end{array}$ & $\begin{array}{l}\text { Choices Mean: } \\
\text { Choices Mean: }\end{array}$ & $\begin{array}{l}20.35^{* *}(99) \\
18.76^{* *}(96)\end{array}$ & & \\
\hline
\end{tabular}

Panel C. Mean of Default Measure

\begin{tabular}{|c|c|c|c|c|c|}
\hline & \multicolumn{2}{|c|}{ Low Similarity } & \multicolumn{2}{|c|}{ High Similarity } & \multirow{2}{*}{$\begin{array}{l}\text { Knowledge } \\
\text { Type Mean: }\end{array}$} \\
\hline & Low Number of Choices & High Number of Choices & Low Number of Choices & High Number of Choices & \\
\hline Low Knowledge & $0.31(32)$ & $0.09(23)$ & $0.21(24)$ & $0.38(21)$ & $0.25^{* \star *}(100)$ \\
\hline High Knowledge & $0.00(22)$ & $0.04(26)$ & $0.04(24)$ & $0.07(28)$ & $0.04^{* * *}(100)$ \\
\hline & $0.19(54)$ & $0.06(49)$ & $0.13(48)$ & $0.20(49)$ & \\
\hline Similarity Mean: & 0.1 & (103) & & (97) & \\
\hline & $\begin{array}{l}\text { Low Number } \\
\text { High Number }\end{array}$ & $\begin{array}{l}\text { Choices Mean: } \\
\text { f Choices Mean: }\end{array}$ & $\begin{array}{l}0.16(102) \\
0.13(98)\end{array}$ & & \\
\hline
\end{tabular}


Figure 1. Experiment One- Interaction Effects for Overload Overload Interaction Effects
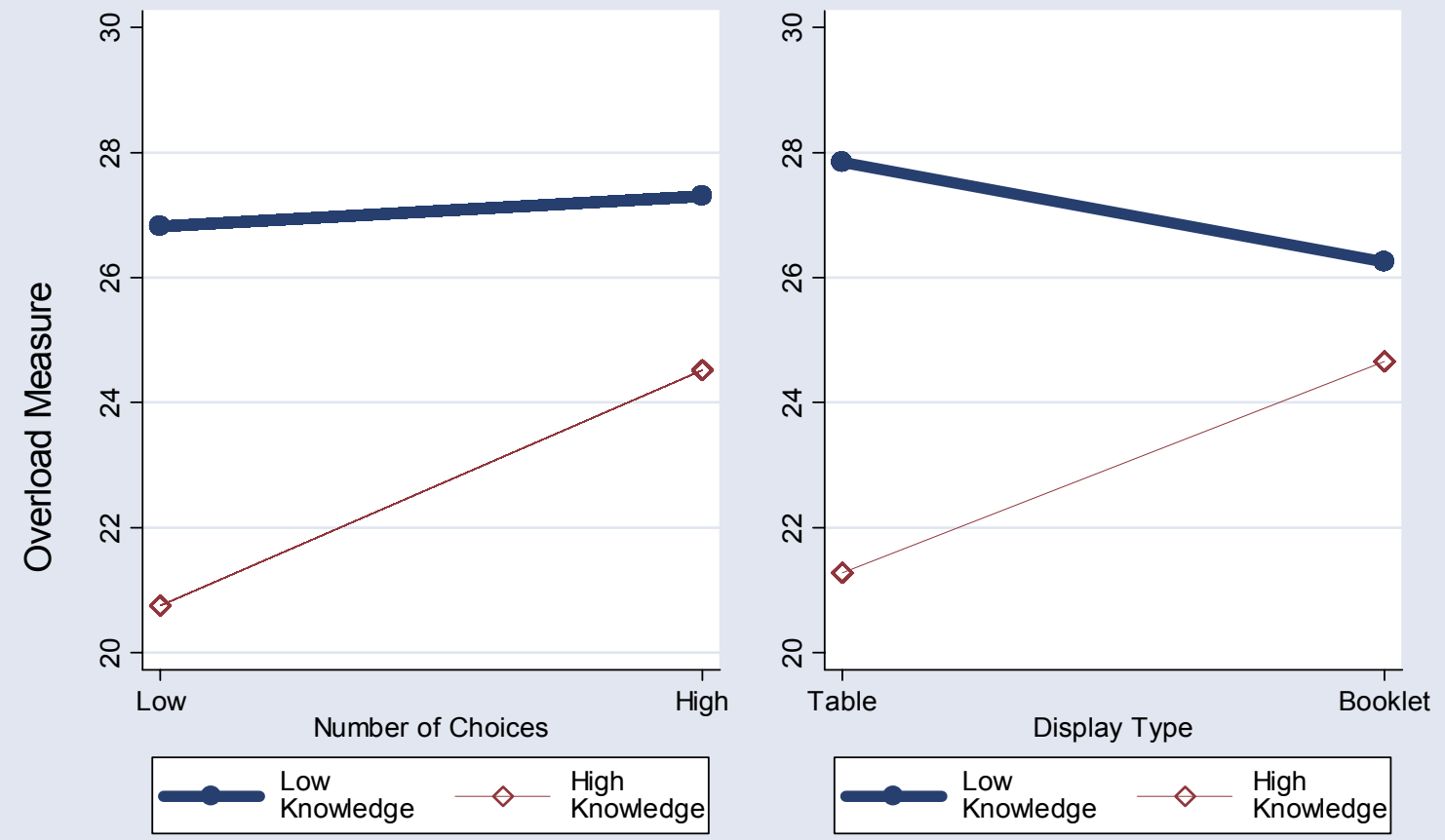

Display Experiment 
Figure 2. Experiment One-Interaction Effects for Default

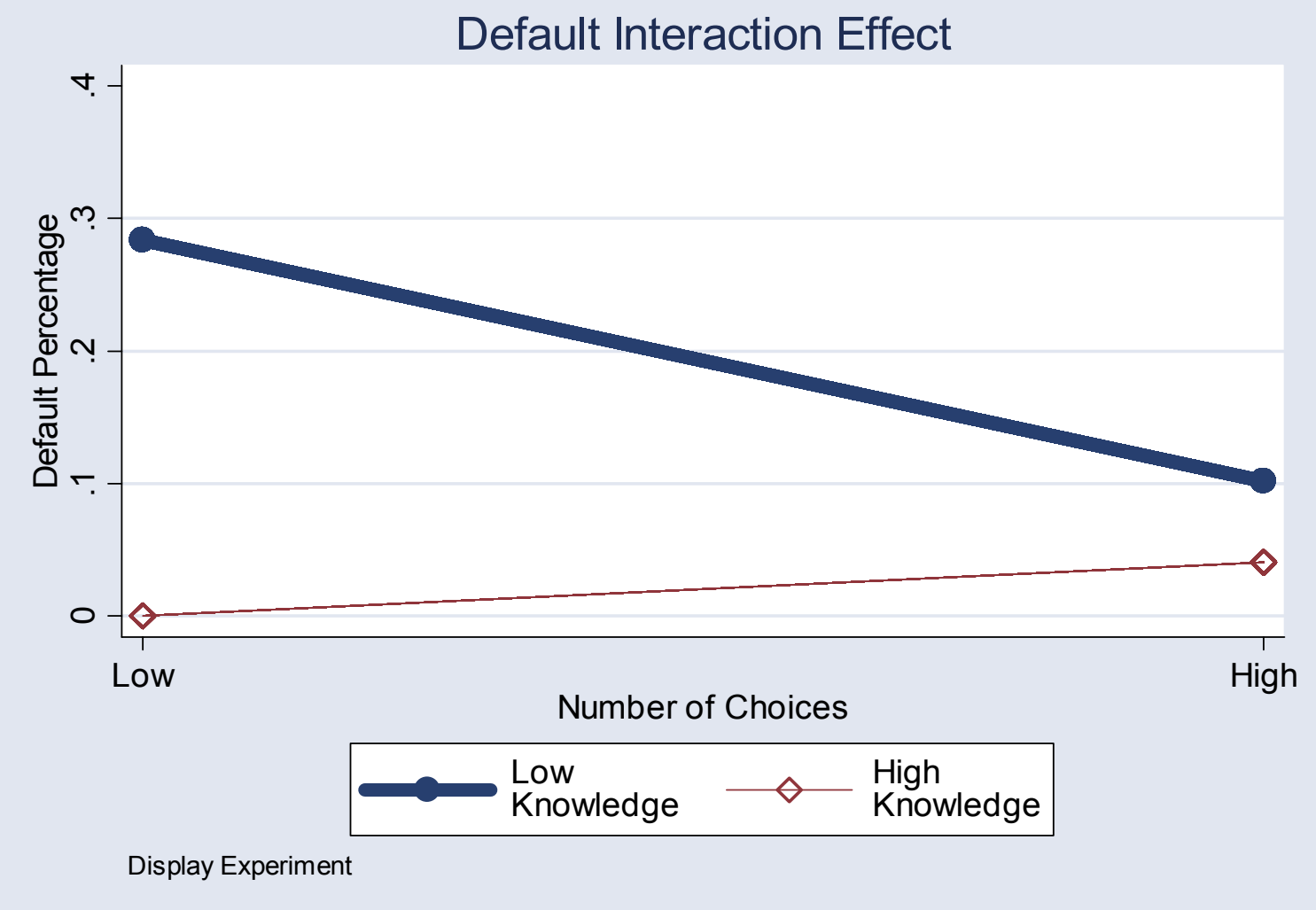


Figure 3. Experiment Two- Interaction Effects for Default

Three Way Default Interaction Effects

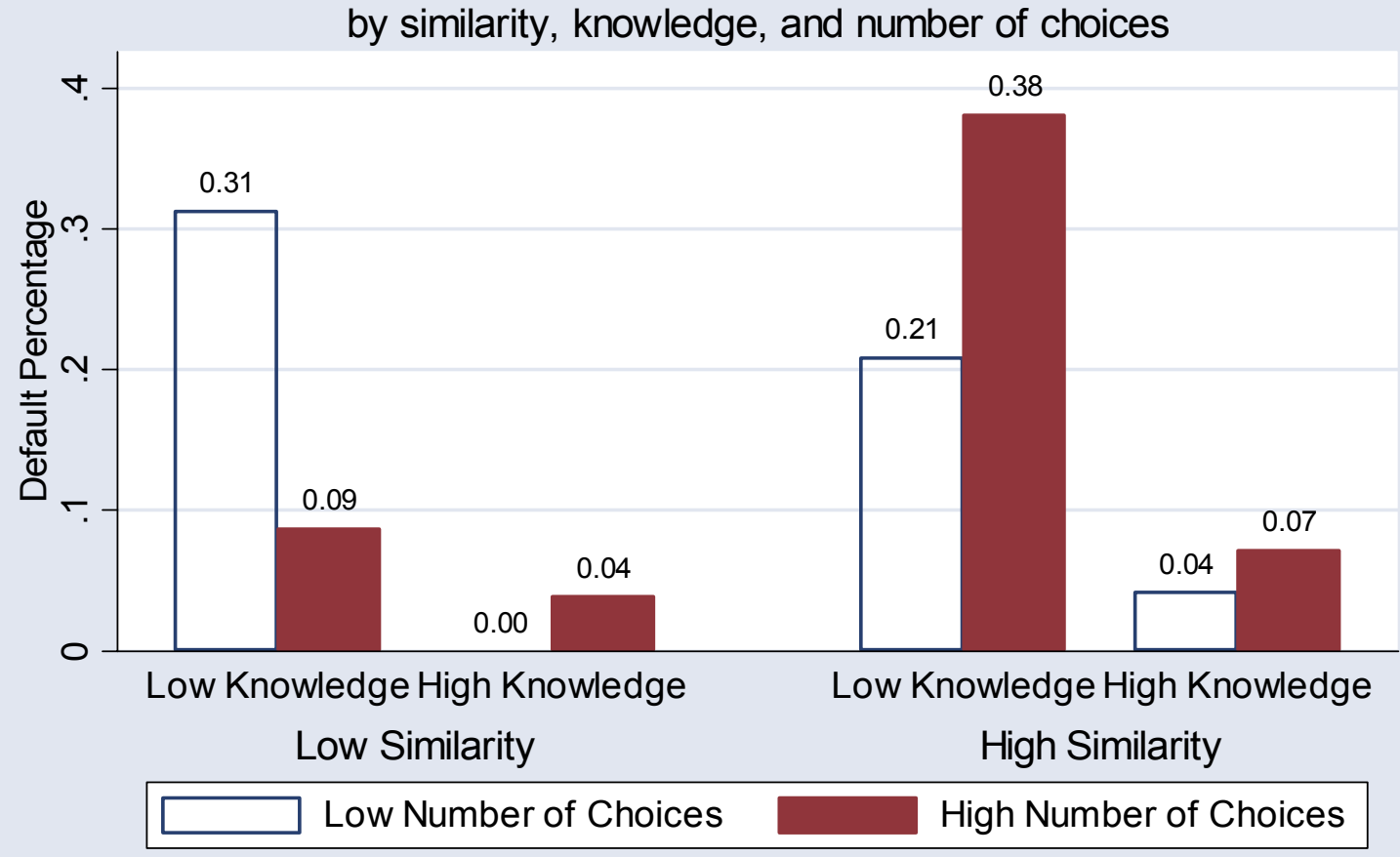

Similarity Experiment 


\section{RECENT WORKING PAPERS FROM THE \\ CENTER FOR RETIREMENT ResearCh AT Boston College}

An Analysis of How Individuals React to Market Returns in One 401(k) Plan Julie Agnew, April 2004

The Effects of Health Insurance and Self-Insurance on Retirement Behavior

Eric French and John Bailey Jones, April 2004

Valuing Assets in Retirement Saving Accounts

James M. Poterba, April 2004

Lifetime Earnings, Social Security Benefits, and the Adequacy of Retirement Wealth Accumulation

Eric M. Engen, William G. Gale, and Cori Uccello, April 2004

The Effect of Social Security on Divorce and Remarriage Behavior

Stacy Dickert-Conlin and Cristian Meghea, April 2004

Household Demand for Variable Annuities

Jeffrey R. Brown and James M. Poterba, March 2004

Lessons for an Aging Society: The Political Sustainability of Social Security Systems Vincenzo Galasso and Paola Profeta, March 2004

Choice and Other Determinants of Employee Contributions to Defined Contribution Plans

Leslie E. Papke, March 2004

Linking Benefits to Marital Status: Race and Diminishing Access to Social Security Spouse and Widow Benefits in the U.S.

Madonna Harrington Meyer, Douglas A. Wolf, and Christine L. Himes, March 2004

Annuitization: Keeping Your Options Open

Irena Dushi and Anthony Webb, March 2004

Living Arrangements and Supplemental Security Income Receipt Among the Aged Melissa M. Favreault and Douglas A. Wolf, February 2004

All working papers are available on the Center for Retirement Research website (http://www.bc.edu/crr) and can be requested by e-mail (crr@bc.edu) or phone (617-552-1762). 